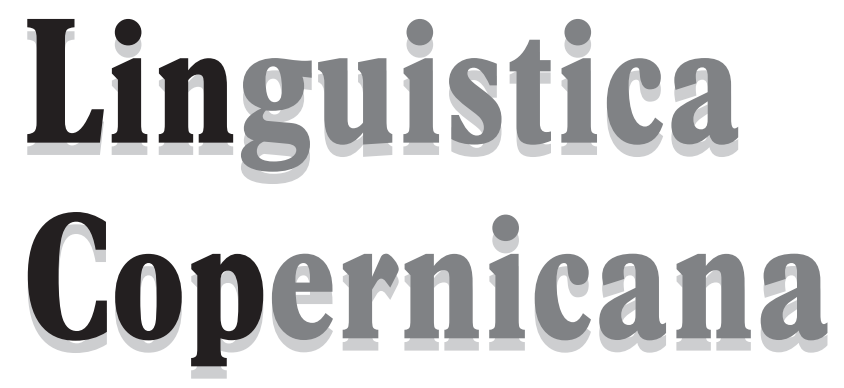

$1(7) / 2012$

WYDAWNICTWO NAUKOWE
UNIWERSytetu MIKOLAJa KOPERNIKA 
REDAKTOR NACZELnY: Maciej Grochowski

Rada Redakcyjna: Ireneusz Bobrowski (Kraków), Andrzej Bogusławski (Warszawa), Gerd Hentschel (Niemcy, Oldenburg), Axel Holvoet (Litwa, Wilno), Krystyna Kleszczowa (Katowice), Roman Laskowski (Kraków), Jarmila Panevová (Czechy, Praha), Jens Nørgård-Sørensen (Dania, Kopenhaga), Zuzanna Topolińska (Macedonia, Skopje), Daniel Weiss (Szwajcaria, Zurich), Anna Wierzbicka (Australia, Canberra)

Kole gi u m R e D K C Y J e: Maciej Grochowski, Krystyna Kallas, Irena Sawicka, Piotr Stalmaszczyk

S E K R ETA R Z R E D A K C I: Iwona Kaproń-Charzyńska

A D R E S R E D A K C J I: Instytut Języka Polskiego UMK, 87-100 Toruń, ul. Fosa Staromiejska 3, e-mail: lincop@umk.pl,www.linguistica.umk.pl

OKŁ A D K A: Monika Pest

(C) Copyright by Wydawnictwo Naukowe Uniwersytetu Mikołaja Kopernika

Toruń 2012

ISSN 2080-1068

Wersją pierwotną (referencyjną) czasopisma jest wersja papierowa.

WYDAWNICTWO NAUKOWE UNIWERSYTETU MIKOEAJA KOPERNIKA

Redakcja: ul. Gagarina 5, 87-100 Toruń

tel. (56) 6114295 , tel./fax 6114705

e-mail: wydawnictwo@umk.pl

Dystrybucja: ul. Reja 25, 87-100 Toruń

tel./fax (56) 61142 38, e-mail: books@umk.pl

www.wydawnictwoumk.pl

Druk: Wydawnictwo Naukowe UMK 


\section{Funkcjonalna interpretacja tekstów historycznych Dwa typy prolepsy w języku greckim na przykładzie Medei Eurypidesa (248-249) i Ewangelii wg św. Jana (12, 12-13)}

Słow a klucze: analiza funkcjonalna, temat, remat, szyk, greka, łacina, partykuła, koniunktyw, gár, dé, prolepsis, Medea, Ewangelia wg św. Jana, báion 'gałąź palmowa', foiniks I 'palma, gałąź palmowa', foĩniks II 'feniks'

Każdy wypowiedziany serio tekst języka naturalnego, a w szczególności zdanie, można analizować jako odpowiedź na jakieś wcześniej zadane pytanie bądź jakąś wcześniejszą wypowiedź1. Język ma charakter dialogiczny, co uznaje się za jedno z uniwersaliów językowych (por. m.in. Hockett 1979: 215). Na ogół rzadko wypowiadamy się w trybie soliloquium, a w tych sytuacjach, kiedy tak robimy, to w gruncie rzeczy nasze mówienie trzeba najczęściej traktować jako dialogizowanie z samym sobą. „Partnerami” sytuacji mówienia mogą być m.in. osobowi uczestnicy stanu rzeczy wyrażonego takim a takim zdaniem czy szeregiem zdań, nadawca pewnej wypowiedzi z jej

1 Przyjmuję za Zofią Zaron (2009: 17-30), że wypowiedzenie, którego wariantem jest konkretna wypowiedź, składa się z tematu (obiektu zlokalizowanego poza zdaniem w sensie węższym) i ze zdania. To zaś konstytuowane jest przez składnik zdaniotwórczy wraz z kompletowanymi przez niego elementami składniowymi, wśród których może się znaleźć wykładnik tematu. 
podmiotem, nadawca wypowiedzi z samym sobą. Językowymi wykładnikami czynności mownych, o które tu głównie chodzi, są przede wszystkim: kontur intonacyjny wypowiedzi, szyk, niektóre typy konstrukcji syntaktycznych (m.in. parenteza metatekstowa, pasywizacja, zdania rozszczepione, czyli tzw. clefting), pewne klasy leksykalne (np. partykuły, spójniki, przysłówki metapredykatywne, rodzajniki, zaimki anaforyczne) oraz wykładniki morfologiczne (np. morfemy wyznaczające składniki realizujące pozycję tematyczną czy orzecznikową). Wszystkie one są sygnałem decyzji kogoś, kto konstruując jakąś wypowiedź, dobiera odpowiednie strategie, aby o c z y m ś powiedzieć c o ś.

Teoretyczny model obserwacji rozczłonkowania wypowiedzi na elementy tematyczne (o czymś) i rematyczne (coś) został zaproponowany przez praskich funkcjonalistów (por. np. Mathesius, Havránek, Skalička w: Dušková i Vachek 1983$)^{2}$. Jest on stosowany przede wszystkim do analizy języków

${ }^{2} \mathrm{~W}$ literaturze przedmiotu poświęconej strukturze informacyjnej wypowiedzenia (jego perspektywie funkcjonalnej) nie ma zgodności ani co do tego, czy jest to struktura wpływająca na semantyczną czy pragmatyczną warstwę wypowiedzenia, ani co do sposobów rozumienia podstawowych dychotomii wykorzystywanych w ujęciach funkcjonalnych (temat vs remat; dane (given) vs nowe (new); topik (topic) vs komentarz/fokus-centrum informacyjne (comment/focus); tło (background) vs fokus (focus)). Większość badaczy zgadza się z tym, że struktura informacyjna jest realizowana w wypowiedzeniu i odnosi się tak do jego kontekstu, jak i stanu wiedzy interlokutorów. W niniejszym opracowaniu przyjmuję, że struktura informacyjna jest strukturą nadrzędną wobec wypowiedzenia, i że może ona być realizowana w zależności od języka za pomocą różnych językowych środków systemowych i pozasystemowych (intonacyjnych, fonologicznych, morfologicznych, leksykalnych, składniowych, tekstowych, kontekstowo-konsytuacyjnych). Przyjmuję także, że główne opozycje tej struktury mogą w zależności od różnych kryteriów opisu, potrzeb informacyjnych i typów tekstów odnosić się do następujących wartości: informacja, o której nadawca sądzi, że jest już znana odbiorcy $v s$ informacja, o której nadawca sądzi, że odbiorca jej jeszcze nie zna (por. Clark i Haviland 1977: 4); porcja wiedzy, o której nadawca myśli, że odbiorca jest jej świadom w momencie wypowiadania takiego a takiego wypowiedzenia vs informacja, którą nadawca, mówiąc coś do odbiorcy, traktuje jako dopiero uświadamianą odbiorcy (por. Chafe 1976: 40); składnik wypowiedzenia reprezentujący starą, wyrażoną wcześniej, dającą się zrekonstruować na podstawie kontekstu informację $v$ informacja niewyrażona wcześniej, niemożliwa do odtworzenia (por. Kuno 1978: 282-283); referent w wypowiedzeniu, na którego temat nadawca zamierza przekazać odbiorcy jakąś wiedzę, o czymś go w związku z tym referentem poinformować vs predykacja, za pomocą której nadawca orzeka coś o referencie (por. Gundel 1988: 210, 212). Wymienione powyżej charakterystyki należą do różnych poziomów opisu. Przytaczam je jednak ze względu na to, że niektóre z nich mogą stanowić punkt wyjścia do analizy tekstów dawnych. 
współczesnych. Językoznawstwo historyczne jest również zainteresowane tym, w jaki sposób dawne języki realizowały potrzeby komunikacyjnej wyrazistości i stylistycznej ekspresji. Badanie pod tym względem języków dawnych, co do których brakuje nam kompetencji językowych, jest bardzo trudne, choć do pewnego stopnia także możliwe. Metody funkcjonalne są wykorzystywane do opisu m.in. starohebrajskiego, wedyjskiego, greki, łaciny, staro-górno-niemieckiego, staroangielskiego i innych języków (por. Panhuis 1981, 1982, 1984a; Battye i Roberts 1995; Disse 1998; Hinterhölzl i Petrova 2009; Westergaard 2009; Ferraresi i Lühr 2010a; Spevak 2010)33.

Podstawowe problemy, które utrudniają zastosowanie metod funkcjonalnych do badania tekstów w językach, które znamy wyłącznie z przekazów pisemnych dotyczą wiarygodności źródeł i autentyczności zawartych w nich konstrukcji składniowych. Mogły one dotrwać do naszych czasów w postaci zniekształconej, mogły być kalkami z innych języków, zwłaszcza w przypadku tekstów tłumaczonych, mogły wreszcie - w zależności od typu i przeznaczenia danego tekstu - nie odpowiadać neutralnym wypowiedziom.

W badaniach funkcjonalnych weryfikacja hipotez odbywa się przede wszystkim poprzez obserwację korelacji między prozodią a strukturami składniowymi. Nie dysponujemy jednak w przeważającej mierze przypadków ani pozytywnymi, ani negatywnymi bezpośrednimi informacjami o tym, w jaki sposób konstrukcje tekstów dawnych były wypowiadane. Pewnych danych może dostarczać grafia, np. znaki diakrytyczne, łączna pisownia wyrazów, sugerująca, że wypowiadano je na jednym zestroju akcentowym, wyróżnianie niektórych form wielką literą, specjalne oznaczenia granic prozodycznych itp. ${ }^{4}$ Niemniej jednak o żadnym z tych potencjalnych wskaźników odnoszących się do prozodii nie sposób wypowiedzieć się konkluzywnie, zawsze będą one rodziły wątpliwości i zawsze będziemy narażeni na niepełną rekonstrukcję warstwy suprasegmentalnej wypowiedzeń tekstów pisanych.

3 Prac poświęconych różnym aspektom funkcjonalnym języków dawnych jest bardzo wiele. Zestawienie pełnej bibliografii na ten temat znacznie przekraczałoby ramy tego artykułu, dlatego wskazane pozycje należy traktować jedynie jako przykładowe.

${ }^{4}$ Niektóre $\mathrm{z}$ tych sposobów można odnaleźć także w tekstach staropolskich, por. Ps 31(32), w. 4 z Psatterza floriańskiego: Bo wedne ywnoczi vczofzila fe ieft nademnó róka twoia $\mid$ obroczil iefm fe wubo/ztwe moiem | gdi fe fyidze tarn (Bo we dnie i w nocy uciążyła się jest nade mną ręka twoja, obrocił jeśm się w ubostwie mojem, gdy się syjdzie tarn). 
W przypadku przekazów, które są przedmiotem zainteresowania lingwistyki historycznej, badania struktury informacyjnej koncentrują się na obserwacji szyku. Źródłem jednak uogólnień dokonywanych na tej podstawie są analizy języków współczesnych, w których w normalnym, niekontrastywnym i nieemfatycznym szyku końcową pozycję w zdaniu zajmuje jego najbardziej informatywny element, właściwy remat. Porządek linearny wypowiedzenia od tematu do rematu traktowany jest zatem przez niektórych badaczy języków dawnych jako jeden z uniwersalnych środków kodowania struktury tematyczno-rematycznej (a zatem struktury wiedzy).

Paul Kiparsky (1995: 153) na podstawie pewnych faktów z języków współczesnych oraz języków staroangielskiego, staroislandzkiego, staro-górno-niemieckiego oraz z uwzględnieniem danych pochodzących z sanskrytu, hetyckiego i greckiego rekonstruuje praindoeuropejską podstawową strukturę nienacechowanego wypowiedzenia ${ }^{5}$ :

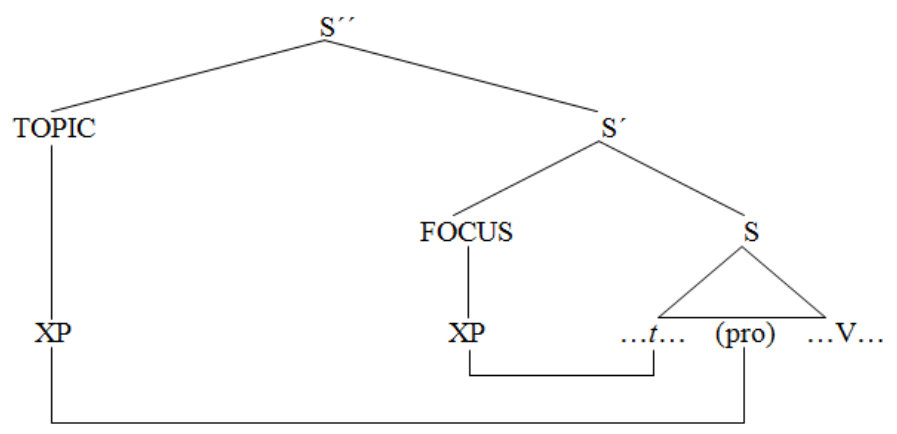

Prajęzyki indoeuropejskie miały w świetle ustaleń Kiparsky’ego szyk z wysuniętą na początek wypowiedzenia pozycją stematyzowaną, po której pojawia się fokus, a w pozycji finalnej znajduje się dopiero czasownik, natomiast zdania rozpoczynające się czasownikiem były według niego emfatycz-

5 „Indo-European had two left-peripheral operator positions [...]. [...] the inner of these positions hosted focal elements, in particular wh-phrases (relative and interrogative) and other focused elements, such as demonstratives [...], and the outer Topic position adjoined to the maximal projection, binds a (possibly null) resumptive pronoun in the argument position [...]. The key difference is that there were no complementizers, and therefore no CP, and no embedding" (Kiparsky 1995: 153). 
ne. Ferraresi i Lühr (2010b: 2-3) w komentarzu do hipotezy Kiparsky’ego piszą, że występowanie czasownika na drugiej pozycji nie jest jednak charakterystyczne ani dla starogermańskich, ani dla staroromańskich języków. Wiele dawnych języków, jak np. gocki czy grecki, dysponowało bardzo rozbudowanym zasobem partykuł, których użycie wiązało się niekiedy m.in. $\mathrm{z}$ wysuwaniem na pozycję pierwszą czasownika w zdaniach o nieemfatycznym i niekontrastywnym charakterze. Nie ma także pewności, czy zmiany neutralnego szyku nie były spowodowane dominującą w jakimś okresie czy dyskursie konwencją lub względami stylistycznymi. Trudno więc ustalić, które elementy dawnych zdań są rzeczywiście tematyczne, które zaś rematyczne, zwłaszcza, że zastosowanie w takich przypadkach procedur operacyjnych, w tym weryfikującego remat testu pytań jest niemal niemożliwe ${ }^{6}$. Nie mamy bowiem wglądu w umysły rodzimych użytkowników dawnych języków, a to oni ostatecznie decydowali, czy dana wypowiedź może być lub nie odpowiedzią na pewne pytanie - dla każdego zdania może istnieć pewien zestaw prawdopodobnych pytań, na które można sensownie odpowiedzieć tym właśnie zdaniem. Aby wskazać remat, jak również nowych referentów dyskursu oraz określić relację między danymi a nowymi referentami, w tekście narracyjnym, niewywołanym żadną znaną nam wcześniejszą wypowiedzią czy znanym pytaniem (a z takimi wypowiedziami mamy przede wszystkim do czynienia, kiedy analizujemy języki dawne), możemy wprawdzie sformułować pytanie, ale będzie ono bardzo ogólne i jedynie prawdopodobne oraz oparte na materiale, którym dysponujemy i który zazwyczaj poddaliśmy już wstępnej interpretacji.

Zasada przyjęta m.in. przez Kiparsky’ego (1995) i Panhuisa (1982: 55 nn.) o rozczłonkowaniu nienacechowanych wypowiedzeń na element tematyczny i rematyczny poprzedzające czasownik sprawdza się w wielu przykładach dawnych języków indoeuropejskich, lecz nie może być powszechnie zastosowana jako nawet dopuszczająca wyjątki reguła w stosunku do wszystkich typów zdań. W niektórych bowiem zdaniach zakończonych czasownikiem

${ }^{6}$ Na temat testu pytań por. Hatcher (1956); Daneš (1970); Maas (1972); Sgall (1986). „Es zeigt sich, dass zu einer jeden Aussage eine Ergänzungsfrage existiert, die (mit ihrem Fragewort) gerade nach dem Rhema der Aussage fragt. Es ist gerade das Rhema, was die «Ergänzung» der betreffenden Frage bildet. [...] Jeder Aussage kann eine Menge von Ergänzungsfragen beigeordnet werden, die alle möglichen Typen der Kontexte und, folglich, alle in Betracht kommenden verschiedenen Mitteilungsperspektiven der gegebenen Aussage repräsentiert" (Daneš 1970: 73-74). 
najbardziej informatywny ich składnik nie zajmuje bynajmniej pozycji bezpośrednio przed tym czasownikiem, por.:

(2)

$\begin{array}{lllll}\begin{array}{l}\text { Accidit } \\ \text { zdarza się }\end{array} & \begin{array}{l}\text { etiam } \\ \text { także }\end{array} & \begin{array}{l}\text { repentinum } \\ \text { niespodziewany-NOM }\end{array} & \begin{array}{l}\text { incommodum } \\ \text { klęska-NOM }\end{array} & \begin{array}{l}\text { biduo, } \\ \text { dwa dni }\end{array} \\ \text { quo } & \text { haec } & \text { gesta sunt (Caes. Civ. 1.48.1). } & \\ \text { REL } & \text { te-NOM } & \text { są wypadkami ('były zrobione') }\end{array}$

'Dwa dni po tych wydarzeniach doszło także do niespodziewanej klęski'.

W przykładzie (2) wyrażenie repentinum incommodum 'nieprzewidziana klęska' zostało umieszczone zaraz po czasowniku accido i partykule etiam, po nim zaś znajduje się wyrażenie temporalne biduo, quo haec gesta sunt 'w ciągu dwóch dni od tych zdarzeń'. Zgodnie z hipotezą Kiparsky'ego powinno to być zdanie emfatyczne (to naprawdę SIĘ ZDARZA), jednak jego kontekst każe odrzucić taką interpretację - Cezar informuje w tym fragmencie o tym, co spowodowało, że już trudna sytuacja stała się jeszcze gorsza: rzeczownik incommodum nie pojawia się w jego przekazie wcześniej, ponadto określająca go przydawka (repentinum 'nagły, niespodziewany') jest wyraźnym semantycznym sygnałem czegoś nowego. Czasownik accido zatem jest w tym wypowiedzeniu zapowiednikiem centrum informacyjnego całego wypowiedzenia - repentinum incommodum, a wyrażenie temporalne eksplicytnie (haec) wiąże się z poprzedzającym kontekstem.

Analizowany przykład pokazuje, że hipoteza, wedle której w językach dawnych część rematyczna umieszczana była w pozycji finalnej wypowiedzenia (np. przed czasownikiem), nie sprawdza się w każdym konkretnym przypadku. Na szyk zdań greckich czy łacińskich wpływały nie tylko reguły systemowe, lecz również - o czym była już mowa wyżej - dominujące w danym okresie tendencje $\mathrm{e}^{7}$ i może $\mathrm{z}$ tego właśnie powodu w szeregu przykładów

7 Por.: „The AG [tj. Ancient Greek] word order [...] appears to be both a combination of rules and tendencies, and a combination of systems. As far as the first phenomenon is considered, it is characteristic that it is continuous topics, elements that display some features of the clitic syntactic behaviour, that are most susceptible to variation. Their defining characteristic seems to be best described as the avoidance of prominent positions and an immediate adjacency to them. This brings them to the position behind FSTops 
obserwujemy odmienne typy tematyczno-rematycznego rozczłonkowania wypowiedzeń niż przyjęte przez Kiparsky’ego i innych badaczy ${ }^{8}$.

Szyk większości dawnych języków indoeuropejskich jest wprawdzie określany jako swobodny, lecz nie jest on zupełnie dowolny - rządzą nim bowiem pewne reguły informacyjne związane m.in. z hierarchizacją informacji dyskursywnych ${ }^{9}$. Być może jednak za pomocą analizy uporządkowania linearnego języków dawnych można formułować jedynie przybliżone i ograniczone do pewnego typu dyskursów wnioski, a odkrycie wzorców komunikacyjnych na tej podstawie wciąż wymaga szczegółowych i nie zawsze dających satysfakcję analiz. Można - uogólniając dotychczasowe obserwacje - przyjąć, że zazwyczaj inicjalną pozycję w zdaniu zajmuje wykładnik tematyczności bądź element kontrastywny (por. Pinkster 1990: 171 nn.), choć tego

[tj. frame-setting topics], verbs, and postverbal narrow foci; as the postverbal position is by far the most frequent [...], I considered it appropriate to treat it as a rule and to relegate the other two positions to the field of variation. The variation in the placement of FSTops in the minor system is well functionally motivated: the iconical tendency for frame-setting expressions to occur as close to the beginning of a clause as possible may sometimes override the structurally defined rule of narrow focus placement. All other elements occur in their respective positions with such consistency that the only appropriate term for their placement is rule, not tendency" (Matić 2003: 626).

8 W niektórych przypadkach analiza funkcjonalna zdań dawnych może być konfrontowana $\mathrm{z}$ obserwacjami zawartymi we współczesnych im traktatach retorycznych. Taką metodę proponuje de Jonge (2007), który zauważa, że między antycznymi opisami języków greckich i łacińskich a ich współczesnymi analizami funkcjonalnymi istnieje szereg podobieństw (m.in. zwracanie uwagi na komunikatywną rolę języka i przyjmowanie, że przedmiotem opisu jest tekst, nie zaś izolowane zdanie). Może ona jednak być zastosowana tylko w tych nielicznych przypadkach, w których dysponujemy odpowiednimi źródłami, czyli na gruncie indoeuropejskim głównie do analizy niektórych tekstów greckich bądź rzymskich.

9 Przykładowo szyk grecki od dawna był traktowany albo jako całkowicie arbitralny, albo jako taki, który podlegał nieujmowalnym za pomocą reguł emotywnym potrzebom mówiących. Zdaniem Helmy H. Dik (1995: 12) greckie zdanie obowiązują jednak pewne reguły - składa się ono z dwóch określonych pragmatycznie przedczasownikowych pozycji oraz pragmatycznie nienacechowanej poczasownikowej pozostałej części zdania. Dwie pierwsze pozycje badaczka definiuje jako P1 - topik i PØ - fokus. Pozycja predykatywna jest domyślną pozycją czasownika $(\mathrm{V})$, pozostałe zaś elementy zdania - X (tzn. te, które nie są nacechowane pod względem dyskursywno-pragmatycznym) zajmują linearnie swobodną pozycję poczasownikową. Szyk grecki według Dik nie jest zdeterminowany składniowo, lecz pragmatycznie. W praktyce oznacza to, że topikiem może być zarówno podmiot, jak i dopełnienie. Przykład grecki, który będzie analizowany poniżej przeczy - jak się zdaje - podziałowi wprowadzonemu przez Dik. Wiele dyskusyjnych przykładów przytacza również Matić (2003). 
typu wypowiedzenia nie przeważają znacznie nad układami, w których na wysuniętej lewostronnej pozycji umieszczane są elementy rematyczne. Z kolei wyznaczenie standardowej pozycji rematycznej nastręcza już wiele kłopotów i trudno w tym przypadku wskazać jednolity wzorzec (por. dla łaciny np. Spevak 2010: 29-31).

Przybliżone jednak wnioski na temat struktury informacyjnej dawnych wypowiedzeń możemy formułować dzięki obserwacjom poszczególnych tekstów zbliżonych do siebie pod względem zarówno czasowym, jak i genologicznym. Petrova i Solf (2009: 144-153) zaproponowali wielopoziomowy model opisu struktury informacyjnej tekstów historycznych, polegający na rezygnacji z bezpośredniego wyznaczania jej głównych kategorii (por. przyp. 2), a zmierzający do przypisywania poszczególnym składnikom zdań prawdopodobnego zestawu cech związanych z tymi kategoriami struktury informacyjnej ${ }^{10}$.

W moim przekonaniu punktem wyjścia analizy funkcjonalnej tekstów dawnych powinna być ich dokładna analiza składniowo-semantyczna, a dopiero potem eksplicytna bądź implicytna odpowiedź na pytanie o to, czy na podstawie analizy gramatycznej wypowiedzenia oraz analizy jego kontekstu (w tym również za pomocą możliwych do zrekonstruowania pytań oraz wskazania elementów kontekstowo zależnych i kontekstowo niezależnych), a niekiedy i danych ogólnokulturowych możemy:

a) wyodrębnić informację, o której nadawca może sądzić, że jest już znana odbiorcy oraz wyodrębnić informację, o której nadawca może sądzić, że odbiorca jej jeszcze nie zna;

10 Procedura Petrovej i Solfa (por. Petrova i Solf 2009: 145-147, 149-150) polega na weryfikacji nowego referenta za pomocą kilku testów operacyjnych: (1) informacji metatekstowej: Opowiadam ci o X; (2) gdy referent jest wyrażony składnikiem dopełnieniowym lub gdy jego wykładnikiem jest drugi argument w zdaniach z czasownikami przechodnimi: W..., widzieliśmy $X$-a (we saw X); (3) wskazaniu podmiotu w konstrukcjach egzystencjalnych lub narracyjnych typu Pewnego razu byt...; (4) w zdaniach z czasownikami ruchu wyrażającymi pojawienie się kogoś i czegoś: Nagle, tuż przed naszymi oczami, pojawit się X...; (5) określeniu, o czym jest mowa: A mówi o X, że X...; (6) sprawdzeniu, czy wyrażenia referencjalne zawierają jakieś wykładniki określoności bądź nieokreśloności; (7) zbadaniu, czy któryś ze składników wypowiedzenia jest częścią konstrukcji syntaktycznej (frazy) związanej z tematycznością (np. 'jeżeli chodzi o...'). Ponadto autorzy proponują zweryfikowanie tak uzyskanych informacji z innymi danymi: (1) czy niewyodrębnione w powyższy sposób składniki wypowiedzenia są odpowiedzią na występujące wcześniej w tekście pytanie szczegółowe (wh-question) lub czy są rozwinięciem dyskursu albo (2) czy kontrastują z innym składnikiem dyskursu. 
b) wskazać porcję wiedzy, co do której nadawca może być przekonany, że odbiorca może być jej świadom w momencie, w którym odbiera on dane wypowiedzenie oraz wskazać informację, którą nadawca może traktować jako taką, której odbiorca może nie być świadomy;

c) wydzielić takie składniki wypowiedzenia, które reprezentują starą, wyrażoną wcześniej i dającą się zrekonstruować na podstawie kontekstu informację oraz wydzielić takie składniki wypowiedzenia, które wiążą się z informacją niewyrażoną wcześniej i niemożliwą do odtworzenia na podstawie kontekstu;

d) oznaczyć referenta $\mathrm{w}$ wypowiedzeniu, na którego temat nadawca przekazuje odbiorcy jakąś wiedzę oraz oddzielić go od tej części wypowiedzenia, za pomocą której nadawca orzeka coś o tym referencie, o czym nadawca i odbiorca nie mają wspólnej wiedzy.

$Z$ reguły w odniesieniu do tekstów dawnych nasze odpowiedzi będą miały jedynie wartość hipotetyczną i przybliżoną, a elementy tematyczne i rematyczne struktury wypowiedzenia będą wyznaczane przez nas skalarnie - o niektórych z nich będziemy wnioskować, że istnieje większe prawdopodobieństwo, że są to składniki znane niż nieznane, świadome dla odbiorcy niż nieświadome, dane kontekstowo niż niedane, referencjalne niż niereferencjalne.

Przyjrzyjmy się pod tym względem zdaniu wyjętemu z Wojny peloponeskiej Tukidydesa (1, 3, 1-2):

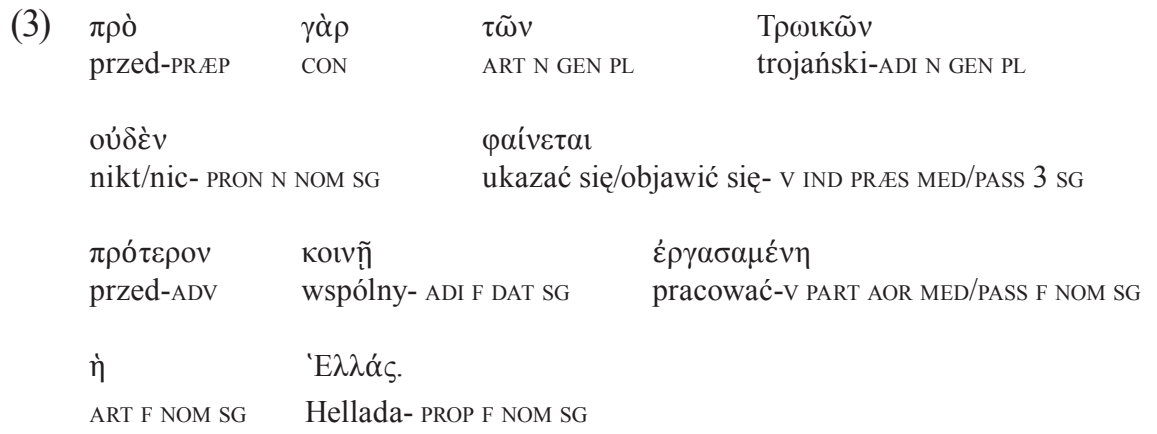

'Przed [wojną] trojańską nie wydała żadnego wspólnego dokonania Hellada' ${ }^{11}$.

11 W tłumaczeniu Kumanieckiego (Tukidydes 1988: 2) to zdanie brzmi następująco: „[...] przed wyprawą trojańską Hellada nie zdobyła się na żaden wspólny czyn”. 
Wypowiedzenia w grece klasycznej zbudowane są zazwyczaj w ten sposób, że na wyeksponowanej pozycji pierwszej umieszcza się wyróżnione z jakiegoś powodu wyrażenie (słowo bądź frazę), po którym następuje pozornie wyłącznie eufoniczne wyrażenie funkcyjne: partykuły ${ }^{12}$ wzmacniające siłę argumentacji bądź wyrażające przeciwstawienie, partykuły emfatyczne, wyrażenia modalne, przysłówki dozdaniowe, niektóre zaimki itp. Zazwyczaj wyrażenia początkowe traktuje się jako tematyczne, natomiast wyrażenia zajmujące drugą pozycję interpretuje się w trojaki sposób: albo jako pragmatyczne elementy wypowiedzi, albo jako składniowe zapowiedniki tego, o czym będzie mowa w głównej części wypowiedzenia, albo jako wyrażenia pojawiające się w zdaniach ze względów fonetycznych (szerzej na ten temat Fraser 2001a: 139-140).

Przykład (3) rozpoczyna temporalny przyimek $\pi \rho o ́$, po którym następuje wyrażenie $\gamma \alpha$ ó $\rho$, które zazwyczaj pełni m.in. funkcję wskaźnika uzasadniania; jest sygnałem nowej informacji (por. S. J. Bakker 2009b: 47). Początek zatem omawianego zdania informuje o tym, że mowa jest o czasie poprzedzającym moment mówienia i o fakcie, że to, co zostało wypowiedziane wcześniej (w poprzednim zdaniu bądź w poprzedzającym omawiane zdanie kontekście) zostanie za chwilę uzasadnione ${ }^{13}$. Można by było zatem sądzić, że wykładnikiem tematu w tym wypowiedzeniu jest przyimek wskazujący na czas, natomiast fraza pokoniunktywna będzie należeć do części rematycznej.

12 Termin partykuła w gramatykach klasycznych często rozumiany jest bardzo szeroko. Denniston (1954: xxxvii) pisze: "Difficult as it is to arrive at a satisfactory definition of particle, an attempt must be made at the outset. I will define it as a word expressing a mode of thought, considered either in isolation or in relation to another thought, or a mood of emotion”. Taki sposób ujęcia ,partykuł” wpłynął na innych badaczy, którzy jednolicie traktują nie tylko rzeczywiste partykuły, lecz również „partykuły łączące”,

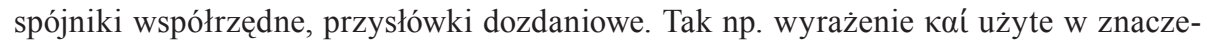
niu 'nawet' bywa klasyfikowane jako przysłówek, natomiast w znaczeniu 'i' - jako spój-

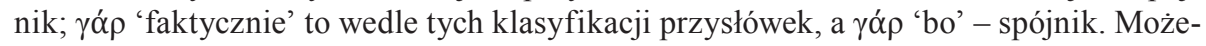
my oczywiście mieć w takich przypadkach do czynienia z homonimią, jednak wyróżnienie homonimów wymaga bardzo drobiazgowej analizy składniowo-semantycznej jednego przekroju synchronicznego, która nie zawsze pozwala na formułowanie ostatecznych wniosków. Szerzej na temat partykuł greckich por. Sobotka (2013).

13 Sicking i van Ophuijsen (1993: 24) uważają, że funkcją ró $\rho$ jest zapowiadanie tej treści, która we wcześniejszym zdaniu była jedynie presuponowana, a w następującym po nim będzie wyrażona eksplicytnie. Duhoux (1997: 39) traktuje partykułę ró $\rho$ jako dyskursywną, typową dla dramatu, a zatem również i dla języka mówionego. Pełni ona jego zdaniem zazwyczaj funkcję prezentatywną, wprowadzającą jakiś tekst. 
Wyrażenie $\gamma \alpha \dot{\alpha} \rho$ jest dawnym złożeniem $\gamma \varepsilon+\not ̋ \rho \alpha-$ partykuła $\gamma \varepsilon$ służyła wyróżnieniu albo wyrażenia, które poprzedzała, albo następującej po niej frazy, natomiast spójnik ő $\alpha$ był wykładnikiem tego, że jakaś fraza odnosi się do czegoś, co zostało powiedziane we wcześniejszym kontekście. Być

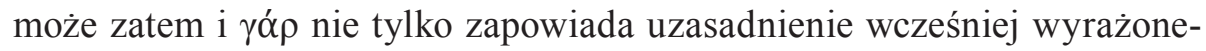
go sądu, lecz także w jakiś sposób wyróżnia lewo- bądź prawostronną frazę z jego najbliższego kontekstu. Jeżeli założymy, że status przyimka $\pi \rho o ́$ w strukturze informacyjnej przykładu (3) jest tematyczny, a następujący po nim koniunktyw (o semantyce zbliżonej w pewnym sensie do polskiego spójnika ponieważ) wyróżnia $\mathrm{z}$ dalszego kontekstu sąsiadującą $\mathrm{z}$ nią frazę

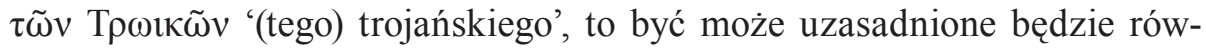
nież uznanie i tego ostatniego wyrażenia za element stematyzowany, por. układ (3a):

(3a) Ponieważ T[emat], dlatego Hellada nie zdobyła się na żaden wspólny wyczyn.

i komplementarny z nim (3b):

(3b) Hellada nie zdobyła się na żaden wspólny wyczyn, ponieważ T.

Wydaje mi się, że determinator towarzyszący substantywizowanemu przymiotnikowi 'trojański' nie tylko pełni funkcję ujednoznaczniającą i deiktyczną, lecz również informuje, że mamy w tym przypadku do czynienia z wydarzeniem znanym odbiorcy, takim, które może służyć dla niego jako „punkt odniesienia"14. Jeżeli tak jest w istocie, to wzmacniałoby to hipotezę o jego tematycznym charakterze. W takiej sytuacji koniunktyw ró $\rho$ umieszczony przed określoną frazą nominalną łączyłby ją z wyrażeniem inicjalnym, wzmacniając je, a także stawałby się wykładnikiem określonego uszczegółowienia referencjalnego grupy tematycznej wyznaczonej we wcześniejszym zdaniu bądź najbliższym kontekście. Natomiast jego funkcja zapowiednika uzasadnienia wcześniejszego twierdzenia odnosiłaby się nie do wszystkich wyrażeń po nim następujących, lecz tylko do tej części wypowiedzenia, które tworzy jego człon predykatywny.

$14 \mathrm{Na}$ temat greckiego rodzajnika i jego użycia z wyrażeniami o prymarnej funkcji atrybutywnej por. S. J. Bakker (2009a: 145-213, 215-269) 
W omawianym przykładzie koniunktyw ma zdecydowanie charakter metadyskursywny, jest on również wykładnikiem swoistego przyłączenia dodatkowego składnika tematycznego ${ }^{15}$, dzięki któremu możliwe jest uszczegółowienie właściwego tematu wypowiedzi, a nawet skomentowanie go, i jako taki można go chyba interpretować w tym zdaniu za pomocą struktury eks-

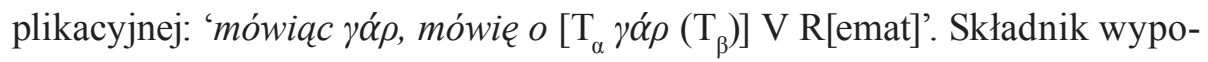
wiedzenia wyznaczony przez koniunktyw $\gamma \alpha$ $\rho$ należy zatem traktować jako oczekiwany, to znaczy taki, za pomocą którego wyraża się treść już znaną lub możliwą do wywnioskowania z kontekstu bądź związaną z ogólną wiedzą wspólną nadawcy i odbiorcy.

W akapitach poprzedzających zdanie (3) czytamy m.in., że zgodnie ze źródłami dostępnymi Tukidydesowi nie było w Helladzie w przeszłości - przed wojną peloponeską, będącą głównym (nadrzędnym) tematem jego dzieła żadnych wielkich wojen ani innych wielkich wydarzeń, a kraj był podzielony na obszary, które zajmowały małe - zrazu wędrowne, a dopiero potem osiadłe - plemiona, spośród których w pewnym momencie szczególnie wyróżnili się mieszkańcy Attyki. Natomiast bezpośredni kontekst poprzedzający przykład (3) mówi o słabości dawnej Grecji:

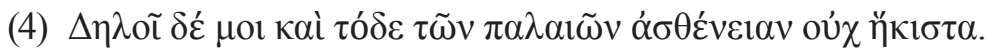

'O dawnej słabości również dla mnie świadczy przynajmniej [to]'.

Wydaje się zatem, że informacja, o której odbiorca powinien już coś wiedzieć odnosi się do będącego przedmiotem opisu kraju sprzed wojny peloponeskiej (ta bowiem jest określona na początku dzieła jako rodzaj cezury w dziejach Grecji), odbiorca także musiał jednoznacznie identyfikować

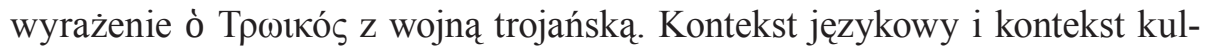

15 Revuelta Puigdollers (2009: 85) zaadaptował do opisu greckich ,partykuł” model zaproponowany przez Simona Dika (1997a, b), wyróżniając trzy typy topików: nowy wprowadzony po raz pierwszy do dyskursu, dany - wymieniony już w dyskursie bądź możliwy do wywnioskowania z innego topiku dyskursu oraz ponownie przywołany $(R e-$ sumed Topic) - związany ze wspólną wiedzą nadawcy i odbiorcy, lecz niewzmiankowany wprost we wcześniejszym dyskursie. Wykładniki tematu mogą istotnie odnosić się do tematu, będącego zawsze obiektem pozazdaniowym, na różnych poziomach: poprzez nawiązanie stosunku do rzeczywistości pozajęzykowej (m.in. oznaczonej za pomoca jakiegoś typu ostensji albo związanej ze wspólną wiedzą interlokutorów) bądź językowej (np. kontekstu wypowiedzenia). 
turowy, wsparte argumentami gramatycznymi, przemawiają za tym, że tematem analizowanego wypowiedzenia jest przeszłość obszaru nazywanego w momencie mówienia Helladą, a sięgająca czasów sprzed wojny trojańskiej

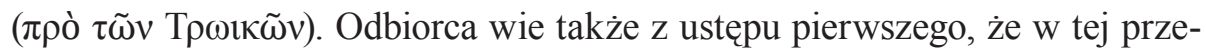
szłości nie wydarzyło się nic godnego uwagi. Być może więc nową informacją wypowiedzenia, jego najbardziej informatywnym elementem jest to, że na tych terenach między dwoma „zreferencjonalizowanymi” okresami (od

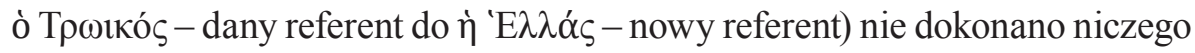
w spólnego. Wspólnotowość i Hellada jawią się - jak się zdaje - centrum informacyjnym omawianego wypowiedzenia, co potwierdza być może kolejne zdanie, w którym mowa jest o tym, że Hellada jako całość ( $\sigma u ́ \mu \pi \alpha \varsigma)$ nie była przed Hellenem, synem Deukaliona, nawet nazywana Helladą:

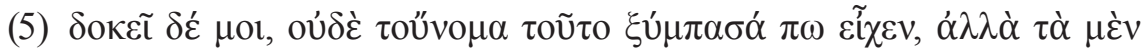

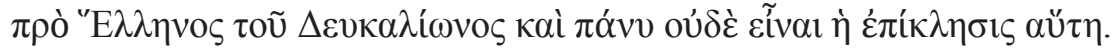

'Moim zdaniem, nie miała jeszcze tej nazwy, przeciwnie, przed czasami Hellena, syna Deukalionosa w ogóle nawet nie istniała taka nazwa'.

Możliwe zatem szczegółowe pytanie dla analizowanego zadania można by było sformułować następująco:

(3c) Dlaczego przed $\left(\mathrm{T}_{\alpha}\right)$ [ = wojną peloponeską $\left(\mathrm{T}_{0}\right)$ od wojny trojańskiej $\left(\mathrm{T}_{\beta}\right)$ ] ten kraj [w domyśle: Hellada] był słaby?

Procedury określania prawdopodobnych wykładników tematyczności zaproponowane przez Petrovą i Solfa (por. przyp. 10) powinny być zestawiane z hipotezami formułowanymi na podstawie obserwacji gramatycznych i semantycznych zmierzających do wykrycia kontekstowo niezależnych elementów analizowanego wypowiedzenia, będących najbardziej prawdopodobnymi kandydatami części rematycznej i elementów kontekstowo zależnych - hipotetycznych wykładników tematu. Wyznaczenie wykładników tematu zdania i jego rematu musi być dokonywane - w zależności od języka - poprzez weryfikację zakładanych intuicyjnie i na podstawie wstępnej interpretacji materiału empirycznego relewantnych w danym języku, w danym okresie jego rozwoju i w danym tekście środków kodowania struktury informacyjnej (od gramatycznych, poprzez leksykalne, aż po tekstowe). Komplet- 
ny opis tych środków winny poprzedzić badania szczegółowe, np. dla języka greckiego: szyku neutralnego i nacechowanego, a w szczególności pozycji inicjalnej wypowiedzeń i ich drugiej pozycji (z uwzględnieniem semantycznego opisu jednostek zajmujących tę pozycję); klityk umieszczanych w wypowiedzeniach; funkcji partykuł, spójników, przysłówków w różnych typach wypowiedzeń; roli i semantyki rodzajników i innych składników o funkcji określającej; znaczenia zaimków osobowych, anaforycznych i in.; ról semantyczno-składniowych i oddziaływań składniowych; inwersji i nieciągłości fraz nominalnych itd.

W dalszej części spróbuję przedstawić takie, uwzględniające zaproponowaną tu perspektywę funkcjonalną, podejście do analizy tekstów greckich na przykładzie dwóch rodzajów prolepsy: składniowej i leksykalnej. Analizie zostaną poddane wypowiedzenia pochodzące z klasycznego okresu języka greckiego (omówię fragment Medei Eurypidesa) oraz z okresu helleńskiego (podstawą będzie ewangeliczna relacja o wjeździe Jezusa do Jerozolimy w przekazie przypisywanym św. Janowi).

\section{II}

Prolepsis (gr. $\pi \rho o ́ \lambda \eta \psi 1 \varsigma$ ‘branie czegoś wpierw, wcześniej, z góry’ utwo-

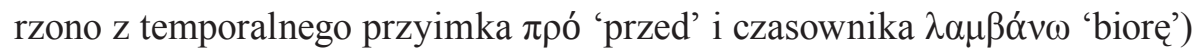
zalicza się do figur retorycznych charakterystycznych dla dialogu i mowy bezpośredniej ${ }^{16}$. Najogólniej rzecz ujmując jest to strategia komunikacyjna polegająca na prezentowaniu za pomocą pewnych wykładników obiek-

16 Inne jej określenia to: anticipatio, anteoccupatio, praesumptio i prokatalepsis. Słownik terminów literackich definiuje ją następująco: ,niezgodna z porządkiem czasowym lub logicznym kolejność pojawiania się jakichś informacji w wypowiedzi: wyprzedzające wprowadzenie elementu logicznie podporządkowanego lub chronologicznie późniejszego, który wymagając dopełnienia antycypuje i zapowiada pojawienie się elementu logicznie nadrzędnego i wcześniejszego. Prolepsis realizuje się w różnych postaciach: w fonetyce, gramatyce, składni i semantyce - jako uprzedzające wystąpienie w tekście pewnych cech fonetycznych bądź też wyrazów o określonej formie, funkcji lub właściwości znaczeniowej (konotacja), a także niesamodzielnych lub niekompletnych członów zdaniowych (antycypacyjny szyk wyrazów); w narracji - jako przestawienie czasowego następstwa wydarzeń (hysteron-proteron, inwersja czasowa fabuły) albo wprowadzenie w relację o obecnej sytuacji bohatera sygnałów wiedzy opowiadacza o przyszłości nie znanej jeszcze bohaterowi [...]; w retoryce - jako uprzedzenie przewidywanych argumentów przeciwnika, ich odparcie, ośmieszenie bądź zlekceważenie, zanim jeszcze zostały sformułowane" (Okopień-Sławińska 2002). 
tów mających dopiero się pojawić, przyszłych zdarzeń, czynności, stanów rzeczy itp. tak, jakby już istniały albo się wydarzyły. Zjawisko jest przedmiotem zainteresowań różnych dziedzin humanistyki, m.in. teorii literatury, w szczególności zaś retoryki (por. np. Genette 1972; Bridgeman 2005; Currie 2007), a także językoznawstwa współczesnego, w tym również tekstologii i pragmatyki (por. Forget 1994; Vincent i Heisler 1999; Mel'čuk 2001; Heisler 2002; Davies 2005), oraz lingwistyki historycznej (por. Gonda 1958a, b; Milner 1980; Touratier 1980; Panhuis 1984b; Christol 1989; Kahn 1993; Wilson 1995; Zewi 1996; Koenen 1997; Belle 2001; Fraser 2001b). W językoznawstwie w zależności od typu wykładnika prolepsy wyróżnia się zazwyczaj prolepsę morfologiczną i składniową, niektórzy badacze postulują także istnienie prolepsis leksykalnej ${ }^{17}$.

Prolepsa morfologiczna to wcześniejsze wystąpienie jakiegoś morfemu w danej jednostce języka, która zwykle nie przyłącza takiego morfemu, i po której następuje inna jednostka leksykalna, która regularnie przyłącza taki morfem:

$$
\begin{array}{lll}
\text { een }[\operatorname{erg}(-e) & \text { leuk-e }] & \text { auto (za: Corver 2007: 177). } \\
\text { bardzo-CONGR } & \text { ładny-CONGR } & \text { samochód }
\end{array}
$$

Prolepsa składniowa to konstrukcja, w której składnik zdania podrzędnego (zazwyczaj jego podmiot) jest antycypowany jako człon podporządkowany w zdaniu głównym (zwykle jako dopełnienie). Innymi słowy, od strony składniowej prolepsa odnosi się do takiej struktury złożonej, w której zdanie nadrzędne zawiera dodatkowy element przeniesiony ze zdania podrzęd-

17 Zaproponowana tu klasyfikacja ma charakter arbitralny. Możliwe by było zapewne wskazanie także innych rodzajów prolepsy, np. tekstowej czy - zgodnie z tym, co pisze Okopień-Sławińska (por. przyp. 16) - fonologicznej. W teorii literatury wymienia się m.in. prolepsę narracyjną, strukturalną i retoryczną: "narratological prolepsis [...] is a form of anticipation which takes place within the time locus of the narrated. It is the anticipation of, or flashforward to, future events within the universe of narrated events. [...] structural prolepsis [...] is a form of anticipation which takes place between the time locus of the narrated and the time locus of the narrator. It is, among other things, the relation between narrated time and the time of narration which is inherent in the preterite tense of classical narration. [...] rhetorical prolepsis [...] is a form of anticipation which takes place between the time locus of the narrator and the time locus of the reader. The classical form of [this prolepsis] is the anticipation of an objection and the preclusion of that objection by incorporating a counter-argument into the discourse" (Currie 2007: 31). 
nego, a zdanie podrzędne - pozbawione tego elementu - same w sobie może niekiedy sprawiać wrażenie składniowo niekompletnego bądź anakolutycznego ${ }^{18}$ :

Who do you think that

she kissed? (za: Corver 2007: 175)

kogo

myślisz, że

ona pocałowała

Natomiast prolepsą leksykalną (najtrudniejszą do wyodrębnienia i najbardziej dyskusyjną ze wszystkich wskazanych przeze mnie jej rodzajów) określam taką konstrukcję, w której jej składnik leksykalny pod względem znaczeniowym (również konotacyjnym) antycypuje treść wyrażoną w konstrukcji późniejszej od proleptycznej, niekoniecznie następującej zaraz po niej, a jednak związanej z nią (podporządkowanej jej) semantycznie bądź pragmatycznie. W takich wypowiedziach ujawnia się zazwyczaj wiedza mówiącego na temat przyszłych zdarzeń, jak w przykładzie (8), w którym o tym, że kobieta nie żyje dowiadujemy się od narratora, zanim jej śmierć stanie się przedmiotem jego wypowiedzi:

(8) Nieboszczka podpłynęła do brzegu i wysiadła z łodzi.

Prolepsa zazwyczaj jest zjawiskiem spontanicznym, charakterystycznym dla tekstów mówionych, z reguły nie traktuje się jej jako celowej transformacji morfologicznej, składniowej czy leksykalnej, choć w rozmaitych przekazach literackich bywa wykorzystywana w sposób zamierzony jako narzędzie

18 Istnieje pewne podobieństwo między prolepsą a kataforą, która także jest rodzajem antycypacji. Katafora jednak wiąże się ze ściśle wyznaczonym układem koreferencjalnym - zaimek kataforyczny odnosi się referencjalnie do jednostki umieszczonej w porządku linearnym za tym zaimkiem. W przypadku prolepsy o takiej zależności nie ma mowy. Igor Mel'čuk (2001: 130-131) inaczej niż ja definiuje prolepsę: "The Prolepsis is a sentence element that is always positioned at the left end of the sentence and is from the purely syntactic viewpoint - very loosely connected to the rest of the sentence: 1. The Prolepsis can always be omitted without disturbing the syntactic organization of the sentence; it is, so to speak, an extra element. 2. The Prolepsis is not governed by the MV, whose valency is fully saturated without it. 3. The Prolepsis is characterized by a special prosody that, as a rule, allows or even requires a pause separating the Prolepsis from the rest of the clause. 4. In case languages, the Prolepsis is in the least marked case - in the nominative". 
służące kolokwializacji wypowiedzi ${ }^{19}$. Z takim zabiegiem mamy chyba do czynienia w Medei Eurypidesa i - jak przypuszczam - w Ewangelii według św. Jana, których fragmenty będą stanowić główny przedmiot analizy ostatniej części artykułu.

W Medei Eurypidesa (248-249) tytułowa bohaterka, żaląc się w epeisodionie pierwszym na własny los porzuconej kobiety, mówi m.in.:

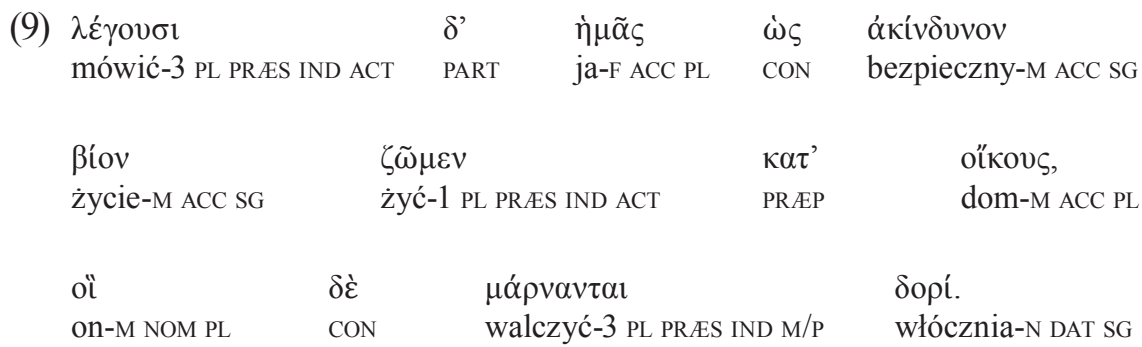

'Mówią [o] nas, że beztroskie życie pędzimy w domu, oni walczą włócznią'.

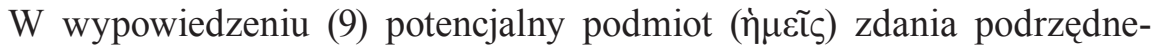
go, którego ośrodkiem jest czasownik $\zeta \tilde{\omega}$ 'żyję', pojawia się w akuzatywie w zdaniu nadrzędnym jako dopełnienie verbum dicendi $\lambda \varepsilon ́ \gamma \omega$ 'mówię'. Jerzy Łanowski, tłumacząc ten fragment tragedii przeniósł zaimek 'my' do części zdania składniowo podporządkowanej, na co być może wpłynęły nie tylko względy stylistyczne:

(9a) Mówia, że niby my żywot bez trwogi / Pędzimy w domu, oni zbrojnie walcza (Eurypides 1989: 380).

Analizowaną konstrukcję trzeba potraktować jako gramatycznie nieregularną (nie tylko dla języka greckiego), ponieważ zazwyczaj argument czasownika standardowo pełni tylko jedną rolę semantyczną, gdy tymczasem

19 Por. Gonda (1958a: 117): "In colloquial speech it is frequent occurrence that a speaker completes the scheme of sentence very soon and then strings on a series of additions and afterthoughts. Among the constructions to which this supplementation gives rise is also so-called proleptic accusative - or, in connection with a number of verbs, genitive -, which in many languages is a frequent syntactical colloquialism". 
w przypadku zdania (9) zaimek $\eta \mu \tilde{\alpha} \varsigma$ jest jednocześnie obiektem przy czasowniku mówienia i agensem czasownika $\zeta \tilde{\omega}$, choć nie zajmuje on pozycji agentywnej i nie ma cech fleksyjnych przypisanych tej roli. Taka konstrukcja, choć anakolutyczna, wydaje się jednak całkowicie informatywna. Jest ona przykładem nie tyle stylistycznego wybryku, ile - od strony uporządkowania linearnego - rozwijania wypowiedzenia za pomocą kolejnych rozbudowywanych elementów dopełnieniowych czy quasi-dopełnieniowych. Przy czym w opisie składniowo-semantycznym element proleptyczny ('my') przypomina konstrukcje $\mathrm{z}$ dopełnieniem dalszym (w analizowanym wypowiedzeniu towarzyszy przechodniemu czasownikowi $\lambda \varepsilon \dot{\gamma}(\omega)$, natomiast zdanie podporządkowane należy interpretować jako dopełnienie propozycjonalne tego właśnie czasownika ${ }^{20}$ :

(9b) [mężczyźni] mówią, że beztroskie życie pędzimy w domu - [mówią, że (to o)] nas.

Wśród badaczy zajmujących się grecką prolepsą nie ma zgody co do tego, w jaki sposób wyjaśniać ten jej typ. Mówi się m.in., że: 1. pozwala on mówiącemu zaprezentować podstawową myśl wypowiedzenia już w zdaniu głównym (Gonda 1958a: 121); 2. jest on podyktowany wyborem pragmatycznym i służy topikalizacji elementu należącego zasadniczo do podporządkowanej, dopełnieniowej i rematycznej części wypowiedzenia (Panhuis 1984b: 36-38); 3. jest to rodzaj transformacji składniowej- podniesienia (raising) składnika podporządkowanej części wypowiedzenia do jego struktury nadrzędnej (por. Panhuis 1984b: 26-27, 36-37; Fraser 2001b: 9)21; 4. powinno się go interpretować jako inwersję neutralnego szyku wpływającą na rozczłonkowanie tematyczno-rematyczne wypowiedzenia (Christol 1989: 68); 5. składnik proleptyczny służy wyrażeniu kontrastu związanego z emfazą (Gonda 1958a: 119).

20 Jednostka 'ktoś o kimś/o czymś mówi, że p’ w języku greckim była realizowana m.in. za pomocą struktury $\lambda \dot{\varepsilon} \gamma \varepsilon \imath+$ ACC, a zatem w analizowanym zdaniu $\grave{\eta} \mu \tilde{\alpha} \varsigma$ mógłby być interpretowany jako argument zdarzeniowy z elipsą czasownika. Byłoby to więc zdanie albo z dwoma argumentami zdarzeniowymi, albo z elipsą czasownika mówienia przy jednym $z$ tych argumentów.

${ }_{21}$ Tego typu interpretacja została odrzucona tak ze składniowego, jak i pragmatycznego punktu widzenia przez van Groningena, Gondę, Lecarme, Milnera i Panhuisa (por. Panhuis 1984b: 36-37). 
Proleptyczny zaimek osobowy (w. 248) w analizowanej strukturze ma charakter anaforyczny - odnosi się do rzeczownika yvvń 'kobieta' z wersu 231, który jest częścią większego passusu na temat roli kobiety w universum greckim:

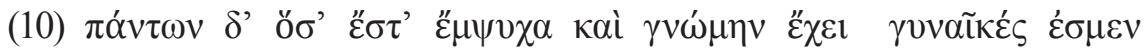

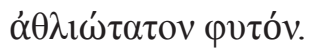

'Ze wszystkich stworzeń żywych i rozumnych / Kobiety, my, to najnędzniejsze z istot' (tłum. za: Eurypides 1989: 380)

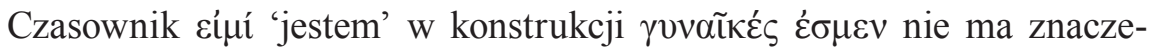
nia egzystencjalnego, lecz należy go traktować z jednej strony jako łącznik, z drugiej zaś, co zostało po części uwidocznione w tłumaczeniu Łanowskiego, jako osobowy dodatkowy wykładnik dictalno-tematyczny w tym zdaniu, a także wykładnik tematu nadrzędnego $\left(\mathrm{T}_{0}\right)$ całego passusu mówiącego o my- kobietach, które $s q$ takie a takie. W takim zatem przypadku w wypowiedzeniu (9) wysunięty na pozycję dopełnieniową w zdaniu głównym semantycznie pojęty podmiot zdania podrzędnego ('my') jest zreaktualizowanym wykładnikiem tematu nadrzędnego. Medea nieprzypadkowo odnosi się do 'my'. Nie mówi ona bowiem o kobietach z pozycji oceniającego obserwatora, ale o samej sobie, odwołując się przy tym do doświadczeń czy sądów tych, na których zrozumienie liczy ${ }^{22}$.

Składnik proleptyczny w wypowiedzeniu (9) poprzedza wyrażenie $\delta \dot{\varepsilon}$, które zazwyczaj w literaturze przedmiotu określa się jako partykułę łączącą bądź spójnik współrzędny (por. przyp. 12), służący do oznaczania granicy między jednostkami dyskursu (Ruijgh 1971: 129-135; E. J. Bakker 1993), np. wprowadzania nowego jego tematu. Presuponuje ono najczęściej istnienie kontrastu (por. Thrall 1962: 50-51). Allan (2007: 105) traktuje wyrażenie $\delta \varepsilon ́$ jako środek służący narratorowi do dzielenia tekstu na dwie niepowiązane ze sobą jednostki tematyczne. W omawianym przykładzie mamy wprawdzie do czynienia z członami przeciwstawnymi (z jednej strony mowa tu o mężczyznach, z drugiej zaś - o my-kobietach), lecz nie można ich na gruncie gramatycznym traktować jako człony równorzędne - kontrast mię-

22 Za pomocą 'my' Medea o z n a c z a pewien zbiór desygnatów, wśród których znajduje się również ona, wypowiadająca swój lament. 
dzy nimi ma charakter tekstowy czy wręcz metatekstowy, a zatem nie mamy pewności, czy funkcją $\delta \varepsilon ́$ w tym przykładzie jest wprowadzanie nowego tematu dyskursu, choć zapewne można traktować to wyrażenie jako cezurę między jedną a drugą jednostką struktury wypowiedzenia. Niewykluczone

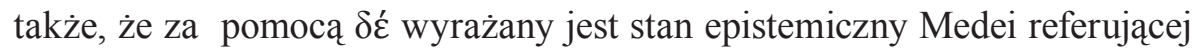
to, co mężczyźni mówią o kobietach, a jednocześnie dystansującej się wobec tego sądu ${ }^{23}$.

Wedle koncepcji Panhuisa (1984b: 28) rematem właściwym analizowa-

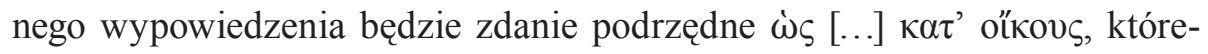
go semantycznie pojęty podmiot został dlatego umieszczony poza tym zdaniem, przed spójnikiem $\omega \varsigma$ jako dopełnienie czasownika $\lambda \dot{\varepsilon} \gamma \omega$, ponieważ ma on według Panhuisa charakter tematyczny. Byłby to jednak bardzo dziwny wykładnik tematu, ponieważ w poprzedzającym kontekście nie odpowiada mu żaden remat. Składnik proleptyczny nawiązuje do dictalno-tematycznego 'jesteśmy' z wersu 231, co zdaniem Panhuisa przemawia za tym, że jest on „związany” z poprzedzającym go kontekstem na zasadzie kontrastu ${ }^{24}$ (Panhuis 1984b: 32):

(9c) $\mathrm{T}_{0}\left[\mathrm{~T}_{\alpha} \delta \dot{\varepsilon}\left(\mathrm{z}\right.\right.$ drugiej strony $\left.\left.\mathrm{T}_{\beta}=\mathrm{T}_{0}\right) \mathrm{R}_{\alpha}\right]$.

Interpretacja Panhuisa nie przekonuje mnie. Zgadzam się z nim, że zdanie podporządkowane w wypowiedzeniu (9) ma charakter rematyczny. Potwierdza to także kolejne wypowiedzenie, w którym Medea orzeka o nowym temacie - domniemanej beztrosce życia kobiet:

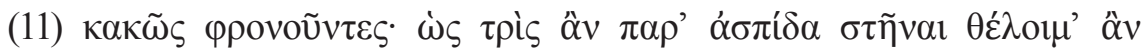

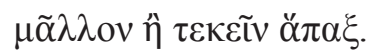

'Mylą się! Wolałabym raczej stanąć trzy razy w boju, niż raz urodzić'.

Nie sądzę jednak, żeby prolepsa była wykładnikiem nowego tematu, ponieważ nie ma w analizowanym zdaniu ani w jego najbliższym kontekście takiego składnika, który byłby względem niej rematyczny.

23 Mielibyśmy tu zatem do czynienia ze słowem, które swoją semantyką zbliżałoby się do takich polskich wyrażeń, jak: rzekomo, jakoby, niby.

$24 \mathrm{~W}$ tłumaczeniu mógłby być oddawany za pomocą formuł wprowadzających $w$ odniesieniu do, ale, jednak, z drugiej strony. 
Od strony składniowej prolepsę należy raczej traktować jako strukturę z innego poziomu niż poziom przedmiotowy wypowiedzenia, tworzy ona wraz z towarzyszącym jej wyrażeniem $\delta \varepsilon$, które funkcjonuje tu nie jak spójnik, lecz jak partykuła, nowe wypowiedzenie, nadbudowane na informacji o mężczyznach, którzy mówią, że kobiety pędzą beztroskie życie, stanowi ona niejako węzeł, w którym splatają się treść przedmiotowa $\mathrm{z}$ treścią nieprzedmiotową związaną z nadawcą wypowiedzenia. Pod wieloma względami prolepsa przypomina parentezę, jednak nią nie jest. Podstawowym dopełnieniem czasownika mówienia - jak to zostało powiedziane wyżej - jest zdanie podporządkowane. Prolepsa natomiast stanowi niejako komentarz do całego wypowiedzenia - (mówiq to a to) - niby o nas - i jako taka ma charakter nietematyczny. Składnikiem zaś rematyzującym w tym wypowiedzeniu jest partykuła $\delta \varepsilon$. Składnik proleptyczny pozostaje oczywiście w związku ze zdaniem następującym po nim - jest on koreferencjalny w stosunku do wykładnika podmiotu tego zdania (w tym przypadku jest to końcówka osobowa czasownika $-\mu \varepsilon v$ ), oraz ze zdaniem, w którym został wskazany temat nadrzędny całej wypowiedzi (por. (10)). Pod tym względem prolepsa reaktualizuje temat nadrzędny, lecz do wypowiedzenia, w którym została umieszczona, wprowadza ponadto dodatkowy element treści z innego poziomu dyskursywnego niż poziom przedmiotowy - jest wraz z partykułą wykładnikiem epistemicznego zaangażowania nadawcy, składnik proleptyczny jest niejako wzięty w cudzysłów, odnosi się do my-kobiet widzianych przez mężczyzn; cudzysłów ten obejmuje całą rematyczną część zdania: mężczyźni mówiq, że „, MY pędzimy beztroskie życie”, ale to nie my-oni nie wiedza, kim jesteśmy, co robimy...

Omówiony powyżej typ prolepsy nie jest charakterystyczny dla języka greckiego. Zazwyczaj towarzyszy ona nie czasownikom mówienia, lecz czasownikom epistemicznym, a niekiedy tylko czasownikom wyrażającym emocje. Zaproponowana tu interpretacja, wiążąca ją z nieprzedmiotowym poziomem wypowiedzenia, domaga się weryfikacji na innych przykładach, w tym także kanonicznych dla niej wypowiedzeniach związanych z myśleniem, sądzeniem itd. Nie ma tu na to wprawdzie miejsca, zakładam jednak, że jeśli w kolejnym omawianym przeze mnie typie prolepsy - prolepsie leksykalnej - potwierdzi się hipoteza o jej statusie, to będzie można z dużą ostrożnością formułować wnioski ogólne odnoszące się tak do prolepsy składniowej, jak i leksykalnej. 
W Ewangelii według św. Jana $(12,12-13)$ w przekazie o wjeździe Jezusa do Jerozolimy czytamy:

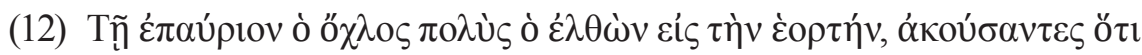

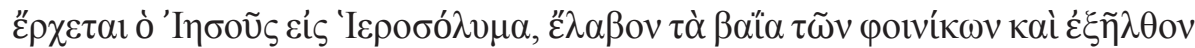

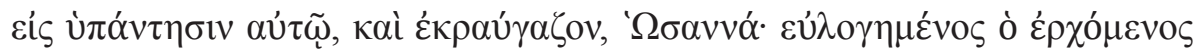

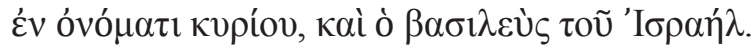

'Następnego dnia wielki tłum, który przybył na święto, usłyszawszy, że Jezus przybywa do Jerozolimy, wziął gałązki palmowe i wyszedł naprzeciw mu na spotkanie, i krzyczeli: Hosanna! Błogosławiony ten, który przychodzi w imię Pana, jak też król Izraela'.

Relacja Janowa jest w tym przypadku bliska opisom synoptyków (Mt 21, 8-9; Mk 11, 8-10, Łk 19, 36-38), choć jednak różni się od nich. Podczas gdy u Jana przybyły na święto tłum wziął gałązki palmowe:

\begin{tabular}{|c|c|c|c|c|c|}
\hline (13) ò & ő $\chi \lambda \mathrm{os}$ & $\pi \mathrm{o} \lambda \dot{u}$ & & ò & $\varepsilon \varepsilon^{\prime} \lambda \alpha \beta$ ov $[\ldots]$ \\
\hline ART & tłum-M NOM SG & wielk & $1 \mathrm{NOM} \mathrm{SG}$ & ART & wziąć-3 PL 2AOR IND ACT \\
\hline$\tau \grave{\alpha}$ & $\beta \alpha i ̈ \alpha$ & & $\tau \tilde{\omega} v$ & pouví & \\
\hline ART & gałązka palmov & ACC PL & ART & palm & lłązka palmowa-M GEN PL, \\
\hline
\end{tabular}

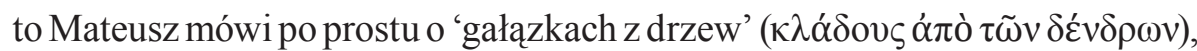

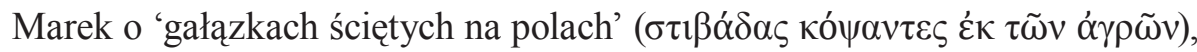
natomiast Łukasz w ogóle nie wspomina o jakichkolwiek gałązkach.

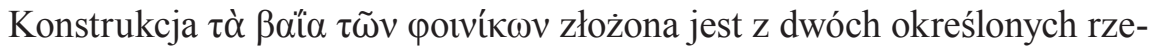
czowników, z których pierwszy znaczy 'gałąź palmowa', natomiast drugi zasadniczo 'palma', jednak czasami był używany w czasach helleńskich w metonimicznym znaczeniu 'gałąź palmowa' (por. Ap 7, 9). Słowo ßóïov pochodzi z egipskiego $b^{\prime} j$ (por. koptyjskie bai); przedostało się ono do języka greckiego w okresie tłumaczenia Septuaginty (Hemmerdinger 1968: 245-246; Beekes i Beek 2010: I, 193); pojawia się wprawdzie kilka razy w Starym Testamencie (m.in. 1Mach 13, 51; PnP 7, 8), lecz w Nowym Testamencie posłużył się nim wyłącznie Jan Ewangelista. Natomiast poıvıкúv jest formą rzeczownika poĩv $\xi$ 'palma', a zwłaszcza 'palma daktylowa'. To appellativum utworzono od nazwy własnej Фoĩvı ‘ 'Fenicjanin' zapewne ze względu na wschod- 
nie pochodzenie palm oraz handel daktylami, którym trudnili się właśnie Fenicjanie. Interesująca nas formacja powstała na gruncie greckim, lecz jej rdzeń, zawierający obcy sufiks -īk-, na pewno nie jest indoeuropejski, być może należy wywodzić go z jakiegoś przedgreckiego substratu językowego, w którym mógł znaczyć 'ciemnoczerwony' albo ‘brązowo-czerwony' (Be-

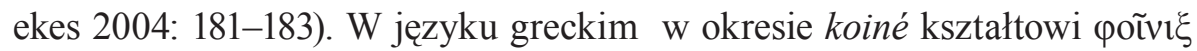
odpowiadało kilka homonimów, wśród których była m.in. być może zapożyczona z egipskiego bjn nazwa mitycznego ptaka czczonego w Egipcie, który odradzał się z popiołów. Grecy sądzili, że oba wyrażenia łączy związek etymologiczny: kiedy feniks ( budował gniazdo na najwyższej palmie ( śmiercią jednak zapalał się od żaru słońca, a ze spalonych popiołów rodził się młody feniks (por. Forstner 1990: 227).

Analizowana fraza mogłaby zatem dosłownie znaczyć:

(13a) Wielki tłum wziął gałązki palmowe palem (daktylowych),

(13b) Wielki tłum wziął gałązki palmowe gałązek palmowych

bądź z odwołaniem do etymologii funkcjonalno-hermeneutycznej:

(13c) Wielki tłum wziął gałązki palmowe feniksa.

Zgodnie z interpretacją (13a) i (13b) ten fragment Ewangelii Janowej należałoby uznać albo za pleonastyczny (Barrett 1978: 347), albo tautologiczny (Lagrange 1948: 325), czego wykluczyć się nie da zarówno z językowego, jak i stylistycznego punktu widzenia, bądź po prostu jako niezbyt zgrabną dla języka greckiego konstrukcję (Hoskyns 1967: 421). Interpretacja pleonastyczna analizowanej frazy budzi zastrzeżenia ze względu na to, że wchodzący w jej skład rzeczownik ßóïov jest słowem zapożyczonym do greckiego późno i jak się zdaje, nawet w okresie koiné rzadko używanym, a co za tym idzie - nie zawsze zrozumiałym. Zestawienie obu tych rzeczowników nie jest chyba przypadkowe. Być może autorowi chodziło właśnie o to, aby słuchacz czy czytelnik zastanowił się nad ukrytym sensem któregoś z nich, czego konsekwencją było to, że taki wyraz przestawał być znakiem przezroczystym, a zaczynał kierować na samego siebie jako właśnie na znak językowy. Dobrym do tego kandydatem nie był jednak jednoznaczny rzeczownik ßóïov, 
lecz poĩv $\xi$ - słowo nie tylko homonimiczne, lecz również konotujące różne znaczenia dodatkowe $\mathrm{i}$ - co nie jest bez znaczenia - w porządku linearnym pojawiające się jako ostatnie analizowanej frazy.

Interpretacja (13c) otwiera miejsce dociekaniom egzegetycznym, pozostającym w zgodzie z klasyczną koncepcją etymologii jako semantyki poszukującej m.in. głębokich i ukrytych sensów wyrażeń języka (por. Sobotka 2011). Charles Harold Dodd (1970: 371) i John Spencer Hill (1982) zakładają możliwość istnienia w tym przypadku aluzji proleptycznej rozumianej przez nich jako lingwistyczny sygnał antycypacji wydarzeń, które dopiero nastąpią - śmierci i zmartwychwstania Jezusa. Ich zdaniem (por. Hill 1982: 134-135)

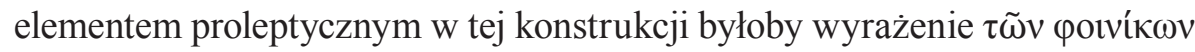
kojarzone w świadomości pierwszych chrześcijan z feniksem-Chrystusem ${ }^{25}$.

Prolepsa - jak to pokazała analiza zdania (9) - od strony funkcjonalnej musi spełniać co najmniej dwa warunki: powinna odsyłać do tematu nadrzędnego całej wypowiedzi oraz powinna w wypowiedzeniu, w którym występuje mieć charakter nietematyczny. Prolepsis jest niejako węzłem, w którym łączą się dwie struktury informacyjne wypowiedzenia: przedmiotowa i metadyskursywna. Ta druga wiąże się z wiedzą nadawcy i jego stosunkiem epistemicznym względem wypowiadanych treści.

W języku greckim rzeczownik poĩv $\xi$ (ptak) pod względem kategorii liczby był prawdopodobnie scharakteryzowany jako singulare tantum. W przykładzie (13) mamy jednak liczbę mnogą, co sprawia, że nie da się stworzyć prostej paraleli między gałązkami a feniksem. Niewykluczone jednak, że

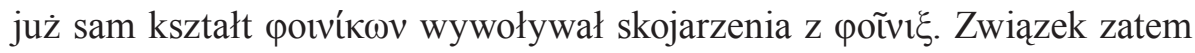
między gałązkami palmowymi a feniksem mógł mieć charakter konotacyjny - zbudowany na podobieństwie dźwiękowym obu słów i zakładanej ich wspólnej podstawie etymologicznej narzucającej się szczególnie w nomina-

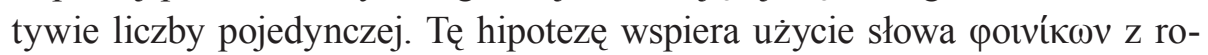
dzajnikiem określonym, którego funkcja tutaj polega przede wszystkim na

25 W literaturze wczesnochrześcijańskiej feniks często jest figurą zmartwychwstania zarówno w wymiarze powszechnym, jak i w odniesieniu do samego Chrystusa (por. Forstner 1990: 228). Wzmianki na ten temat odnajdziemy w pismach Klemensa Aleksandryjskiego, Cyryla Jerozolimskiego, Epifaniusza, Tertuliana, Ambrożego, Zenona

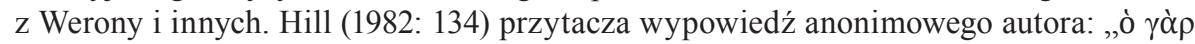

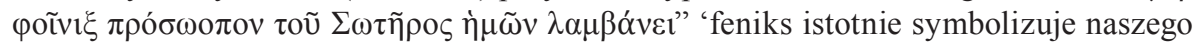
Zbawiciela'. 
wskazywaniu referenta dyskursu jako rozpoznawalnego, możliwego do zidentyfikowania.

Nadrzędnym tematem rozdziału 12 jest zapowiedź śmierci i zmartwychwstania Jezusa. Jezus, świadom nadchodzącej męki, tłumaczy Judaszowi gest Marii, która namaściła Jezusowi nogi drogocennym olejkiem:

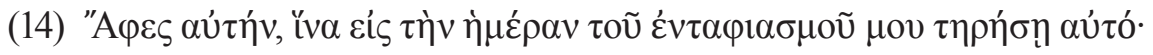
(J 12, 7).

'Zostaw ją; na dzień mojego pogrzebu to chowała'.

Nieprzypadkowo także przywołany jest w tym fragmencie Łazarz, którego Jezus na krótko przed własną śmiercią wskrzesił z martwych, co ma wskazywać na zmartwychwstanie samego Jezusa ${ }^{26}$. Ewangelista relacjonuje tę historię z wiedzą o tym, co nastąpi, nie pozostaje więc bierny na przyszłe wydarzenia (pisząc m.in. o Judaszu, dodaje, że to ten, który miał wydać Jezusa). Buduje on własną relację tak, aby pokazać, że zmartwychwstanie jest konsekwencją całego nauczania Jezusa. Nie jest zatem wykluczone, że autor Ewangelii według św. Jana świadomie wykorzystał w przykładzie (13) związek (konotacyjny lub oparty na homonimii) między 'palmą' czy 'gałązkami palmowymi' a 'feniksem' rozumianym jako symbol śmierci i odrodzenia, do czego odnoszą się kolejne wersety tego przekazu:

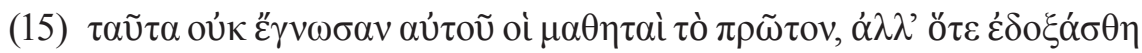

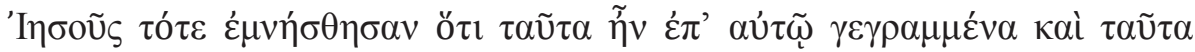

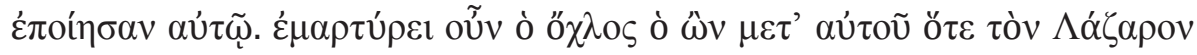

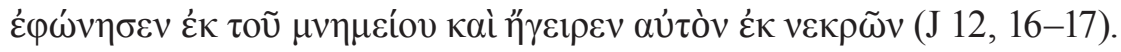

'Uczniowie nie rozumieli z początku tych rzeczy o nim, ale kiedy Jezus został wyniesiony w chwałę, wówczas przypomnieli sobie, że te rzeczy były o nim napisane, i że te mu uczynili. Świadczył więc ten tłum, który był z nim, kiedy Łazarza wywołał z grobu i wybudził go ze śmierci'.

26 Zdaniem m.in. św. Ireneusza (za: Forstner 1990: 317) we wskrzeszeniu Łazarza nie chodzi o uwolnienie go od śmierci, bo ten przecież i tak musiał jej ulec, lecz o potwierdzenie faktu, że Jezus jest ,zmartwychwstaniem i życiem” (J 11, 25). 
Omawiany przykład jest pod względem strukturalno-treściowym paralelny w stosunku do prolepsy składniowej. Wyrażenie $\tau \tilde{\omega} v$ potví $\omega v$ (jeśli istotnie kojarzy się z feniksem, a poprzez to z odrodzeniem po śmierci) odsyła do tematu nadrzędnego dyskursu i antycypuje przyszłe wydarzenia, których kolejną zapowiedź przynoszą już wersety 23-24 tego rozdziału:

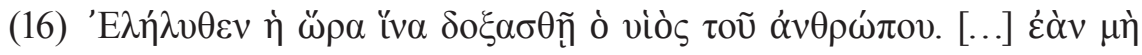

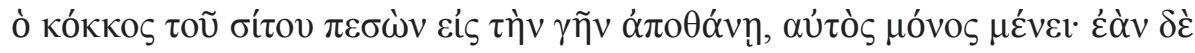

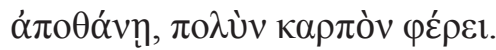

'Nadeszła ('E $\lambda \eta ́ \lambda v \theta \varepsilon v)$ godzina, żeby syn człowieczy został uwielbiony. [...] Jeśli ziarno pszenicy, wpadłszy w ziemię, nie obumrze, pozostanie samo, jeśli zaś obumrze, wielki owoc przynosi'.

W przykładzie (16) Ewangelista zamiast narzucającego się w takim kontekście czasownika 'nadejść' w czasie teraźniejszym wkłada w usta Jezusa czasownik w perfectum. Jest to czas służący do oznaczania stanu obecnego, będącego wynikiem czynności przeszłej dokonanej. Godzina uwielbienia nadeszła, ponieważ była zapowiedziana albo już na poziomie języka się stała w momencie, w którym tłum rzucał pod nogi gałązi palmowe feniksowi temu, który umiera i się odradza.

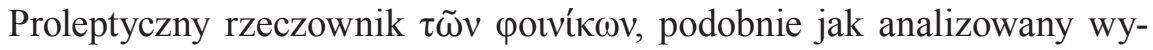

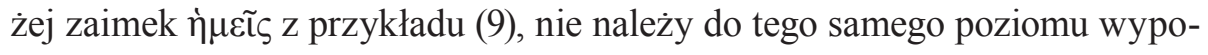
wiedzeniowego, co pozostała część zdania (13), jest on komentarzem egzegetycznym do opisywanych w rozdziale 12 wydarzeń. Został wprowadzony do tego fragmentu nie przez pomyłkę, nieuwagę czy niezgrabność języka, lecz jako świadomy trop, dzięki któremu możliwa była właściwa, zgodna z zamierzeniami autora, interpretacja opisu uczty w Betanii, wjazdu do Jerozolimy i wreszcie śmierci i nieodłącznego od niej zmartwychwstania Jezusa, które dopiero nastąpią. Reaktualizuje on wprawdzie temat główny całej opowieści, lecz sam w sobie nie ma charakteru tematycznego, choć pozostaje w „,związku koreferencjalnym” z następującymi po nim opisami i wypowiedziami: wielki tlum wziat gałazki palmowe - (gałazki) ,feniksa”, ale to nie gałazki palmowe, lecz zapowiedź uwielbienia.

Odpowiednia analiza takiego zjawiska, jakim jest prolepsa, nie może być przeprowadzana wyłącznie na poziomie zdaniowym czy leksykalnym, lecz wymaga obserwacji najwyższego poziomu językowego - poziomu tekstu 
z uwzględnieniem jego struktury, intencji nadawcy itp. Analizę taką winny koniecznie wspierać wnioski wynikające $\mathrm{z}$ obserwacji składających się na ten tekst konstrukcji składniowych, oddziaływań morfologicznych między składnikami fraz i jednostek leksykalnych wraz z ich własnościami. Istotne są nawet najdrobniejsze szczegóły - funkcje partykuł, rodzajników, zaimków itd. Prolepsis jako element struktury wypowiedzeń wpływa w sposób znaczący na wyznaczenie tych elementów, które są wykładnikami tego, o czym się mówi, i tych - za pomocą których wyrażamy to, co się o tym czymś mówi. Analizowane przykłady pokazują, że opis struktury informacyjnej dawnych tekstów może m.in. wspomagać ich interpretacje. Pozwala także docierać do najważniejszej warstwy języka - do języka mówionego.

W moim przekonaniu analiza warstwy komunikacyjnej takich języków, jak np. greka czy łacina, ma istotne znaczenie dla rozwoju współczesnej teorii języka, chociażby stwarzając możliwość porównywania quasi-mówionego i pisanego języka na przestrzeni dziejów. Z drugiej zaś strony, zastosowanie zdobyczy nowożytnego językoznawstwa, w tym narzędzi analizy funkcjonalnej, otwiera przed lingwistyką historyczną nowe perspektywy badawcze, umożliwia wszechstronny opis zachowań i strategii komunikacyjnych, co ma niebagatelny wpływ również na rozumienie dawnych kultur, a także służy rzetelnemu opisowi struktur składniowych, klas leksykalnych, właściwemu odróżnianiu języka poetyckiego od języka quasi-mówionego i języka pisanego. Taka analiza pokazuje również, że w opisie dawnych języków należy uwzględniać przede wszystkim integralne własności właściwych im struktur, a nie przykładać do nich normy, które właściwe są dla innych języków, w tym także języków współczesnych.

\section{Źródła}

Gaius Iulius CAesar, 1950, C. Iuli Caesaris commentarii, wyd.: A. Klotz, Bibliotheca scriptorum graecorum et romanorum Teubneriana, t. 2: Commentarii Belli civilis, Lipsiae: Teubner.

Euripides, 1966, Medea, wyd.: G. Murray, Euripidis fabulae, t. 1, Oxford: Clarendon Press.

Eurypides, 1989, Medea, tłum. J. Łanowski, w: S. Stabryła (red.), Ajschylos, Sofokles, Eurypides. Antologia tragedii greckiej, Kraków: Wydawnictwo Literackie, s. 369-424. 
Nestle - Aland, 1997, Novum Testamentum Graece et Latine, wyd.: E. Nestle et al., Stuttgart: Deutsche Bibelgesellschaft.

Septuaginta, 1971, Septuaginta: id est Vetus Testamentum Graece iuxta LXX interpretes, wyd.: A. Rahlfs, t. 1-2, Stuttgart: Württembergische Bibelanstalt.

Thucydides, 1942, Historiae, wyd.: H. S. Jones i J. E. Powell, Thucydidis historiae, t. 1-2, Oxford: Clarendon Press.

TuKIDYdes, 1988, Wojna peloponeska, tłum. K. Kumaniecki, Warszawa: Czytelnik.

\section{Bibliografia}

Allan R. J., 2007, Sense and Sentence Complexity. Sentence Structure, Sentence Connection, and Tense-Aspect as Indicators of Narrative Mode in Thucydides' Histories, w: R. J. Allan i M. Buijs (red.), Language of Literature. Linguistic Approaches to Classical Texts, Leiden-Boston: Brill, s. 93-241.

BAKker E. J., 1993, Boundaries, Topics, and the Structure of Discourse an Investigation of the Ancient Greek Particle dé, Studies in Language 17(2), s. 275-311.

Bakker S. J., 2009a, Noun Phrase in Ancient Greek. A Functional Analysis of the Order and Articulation of NP Constituents in Herodotus, Leiden-Boston: Brill.

BAKker S. J., 2009b, On the Curious Combination of the Particles $\gamma \alpha \dot{\alpha} \rho$ and oũv, w: S. Bakker i G. Wakker (red.), Discourse Cohesion in Ancient Greek, Leiden-Boston: Brill, s. 41-61.

Barrett C. K., 1978, The Gospel According to St. John. An Introduction with Commentary and Notes on the Greek Text, London: SPCK.

Battye A. i Roberts I. G. (red.), 1995, Clause Structure and Language Change, New York: Oxford University Press.

Beekes R. S. P., 2004, Kadmos and Europa, and the Phoenicians, Kadmos 43(1), s. $167-184$.

Beekes R. S. P. i Beek L. v., 2010, Etymological Dictionary of Greek, t. 1-2, Leiden-Boston: Brill.

Belle G. van, 2001, Prolepsis in the Gospel of John, Novum Testamentum 43(4), s. 334-347.

Bridgeman T., 2005, Thinking Ahead: A Cognitive Approach to Prolepsis, Narrative 13(2), s. 125-159.

Chafe W. L., 1976, Givenness, contrastiveness, definiteness, subjects, topics, and points of view, w: C. N. Li (red.), Subject and Topic, New York: Academic Press, s. $25-55$.

Christol A., 1989, Prolepse et syntaxe indo-européenne, w: G. Calboli (red.), Subordination and Other Topics in Latin. Proceedings of the Third Colloquium on 
Latin Linguistics, Bologna, 1-5 April 1985, Amsterdam-Philadelphia: John Benjamins Publishing Company, s. 65-89.

Clark H. H. i Haviland S. E., 1977, Comprehension and the given-new contrast, w: R. O. Freedle (red.), Discourse Production and Comprehension, Hillsdale, N.J.: Lawrence Erlbaum Associates, s. 1-40.

Corver N., 2007, Dutch 's-prolepsis as a copying phenomenon, w: N. Corver i J. Nunes (red.), The Copy Theory of Movement, Amsterdam-Philadelphia: John Benjamins Publishing Company, s. 175-216.

Currie M., 2007, Prolepsis, w: Idem, About Time. Narrative, Fiction and the Philosophy of Time, Edinburgh: Edinburgh University Press, s. 29-50.

DANEš F., 1970, Zur linguistischen Analyse der Textstruktur, Folia Linguistica 4(1-2), s. $72-78$.

DAVIES W. D., 2005, Madurese prolepsis and its implications for a typology of raising, Language 81(3), s. 645-665.

Denniston J. D., 1930, Notes on the Greek Particles, The Classical Review 44(6), s. $213-215$.

Denniston J. D., 1954, The Greek Particles, Oxford: Clarendon Press.

Dik H., 1995, Word Order in Ancient Greek. A Pragmatic Account of Word Order Variation in Herodotus, Amsterdam: J. C. Gieben.

Dik S. C., 1997a, The Theory of Functional Grammar. Part 1: The Structure of the Clause, Berlin-New York: Mouton de Gruyter.

Dik S. C., 1997b, The Theory of Functional Grammar. Part 2: Complex and Derived Constructions, Berlin-New York: Mouton de Gruyter.

Disse A., 1998, Informationsstruktur im biblischen Hebräisch: sprachwissenschaftliche Grundlagen und exegetische Konsequenzen einer Korpusuntersuchung zu den Büchern Deuteronomium, Richter und 2 Könige, St. Ottilien: EOS Verlag.

Dodd C. H., 1970, The Interpretation of the Fourth Gospel, Cambridge: University Press.

Duhoux Y., 1997, Grec écrit et grec parlé. Une étude contrastive des particules aux Ve-IVe siècles, w: A. Rijksbaron (red.), New Approaches to Greek Particles. Proceedings of the Colloquium held in Amsterdam, 1996, to Honour C. J. Ruijgh on the Occasion of his Retirement, Amsterdam: Gieben, s. 15-48.

DušKovÁ L. i VacheK J. (red.), 1983, Praguiana: Some Basic and Less Known Aspects of the Prague Linguistic School, Amsterdam-Philadelphia: John Benjamins Publishing Company.

Ferraresi G. i LüHr R. (red.), 2010a, Diachronic Studies on Information Structure. Language Acquisition and Change, Berlin-New York: Walter de Gruyter.

Ferraresi G. i LüHr R., 2010b, The Role of Information Structure in Language Change: Introductory Remarks, w: G. Ferraresi i R. Lühr (red.), Diachronic Stu- 
dies on Information Structure. Language Acquisition and Change, Berlin-New York: Walter de Gruyter, s. 1-13.

Forget D., 1994, Anticipation et argumentation: la prolepse, Revue québécoise de linguistique 23(1), s. 61-77.

Forstner D., OSB, 1990, Świat symboliki chrześcijańskiej, ttum. W. Zakrzewska, P. Pachciarek i R. Turzyński, Warszawa: Instytut Wydawniczy PAX.

Fraser B., 2001a, The clause start in ancient Greek: focus and the second position, Glotta 77(3-4), s. 138-177.

Fraser B., 2001b, Consider the Lilies: Prolepsis and the Development of Complementation, Glotta 77(1-2), s. 7-37.

Genette G., 1972, Discours du récit. Essai de méthode, w: G. Genette, Figures III, Paris: Éditions du Seuil, s. 65-273.

Gonda J., 1958a, On the So-Called Proleptic Accusative in Greek, Mnemosyne 11(2), s. $117-122$.

Gonda J., 1958b, 'Prolepsis' of the Adjective in Greek and Other Ancient Indo-European Languages, Mnemosyne 11(1), s. 1-19.

GundeL J. K., 1988, Universals of topic-comment structure, w: M. Hammond, E. Moravcsik i J. Wirth (red.), Studies in Syntactic Typology, Amsterdam-Philadelphia: John Benjamins Company, s. 209-239.

Hatcher A. G., 1956, Syntax and the Sentence, Word 12, s. 234-250.

Heisler T., 2002, La prolepse en discours oral spontané, Université Laval, Faculté des études supérieures, ss. ix+197.

Hemmerdinger B., 1968, Noms Communs Grecs d'Origine Egyptienne, Glotta 46(3/4), s. 238-247.

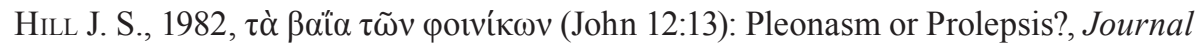
of Biblical Literature 101(1), s. 133-135.

Hinterhölzl R. i Petrova S. (red.), 2009, Information Structure and Language Change. New Approaches to Word Order Variation in Germanic, Berlin-New York: Mouton de Gruyter.

Hocketт C. F., 1979, Zagadnienie uniwersaliów w języku, w: H. Kurkowska i A. Weinsberg (red.), Językoznawstwo strukturalne. Wybór tekstów, Warszawa: Państwowe Wydawnictwo Naukowe.

Hoskyns E. C., 1967, The Fourth Gospel, London: Faber and Faber.

Jonge C. C. DE, 2007, From Demetrius to Dik. Ancient and Modern Views on Greek and Latin Word Order, w: R. Allan i M. Buijs (red.), Language of Literature. Linguistic Approaches to Classical Texts, Leiden: Brill, s. 211-241.

Kahn C. H., 1993, Proleptic Composition in the Republic, or Why Book 1 Was Never a Separate Dialogue, The Classical Quarterly 43(1), s. 131-142. 
Kiparsky P., 1995, Indo-European Origins of Germanic Syntax, w: A. Battye i I. Roberts (red.), Clause Structure and Language Change, New York-Oxford: Oxford University Press, s. 140-167.

Koenen K., 1997, Prolepsen in alttestamentlichen Erzählungen: eine Skizze, Vetus Testamentum 47(4), s. 456-477.

Kuno S., 1978, Generative Discourese Analysis in America, w: W. U. Dressler (red.), Current Trends in Textlinguistics, Berlin-New York: Walter de Gruyter, s. $275-294$.

Lagrange M.-J., 1948, Évangile selon Saint Jean, Paris: J. Gabalda et Cie., Ëditeurs.

MAAs U., 1972, Subjekt, Präsuppositionen, mein Freund Falk und das Ungeheuer von Loch Ness, Linguistics 10(93), s. 44-69.

Matić D., 2003, Topic, focus and discourse structure: Ancient Greek word order, Studies in Language 27(3), s. 573-633.

Mé'čuk I. A., 2001, Communicative Organization in Natural Language: The Semantic-communicative Structure of Sentences, Amsterdam: John Benjamins Publishing Company.

Milner J.-C., 1980, La prolepse en grec ancien, Lalies: Actes des Sessions de Linguistique et de Littérature Paris 1, s. 39-52.

Oкорień-SŁawińska A., 2002, Prolepsis, w: J. Sławiński (red.), Słownik terminów literackich, Wrocław-Warszawa-Kraków: Zakład Narodowy im. Ossolińskich Wydawnictwo, s. 437.

Panhuis D. G. J., 1981, Word Order, Genre, Adstratum: The Palace of the Verb in Caesar's Topographical Excursus, Glotta 59, s. 295-308.

Panhuis D. G. J., 1982, The Communicative Perspective in the Sentence. A Study of Latin Word Order, Amsterdam-Philadelphia: John Benjamins Company.

Panhuis D. G. J., 1984a, Archaic and Contemporary Speech: Word Order in the Formula deum virtute in Plautus, Indogermanische Forschungen 89, s. 26-28.

Panhuis D. G. J., 1984b, Prolepsis in Greek as a Discourse Strategy, Glotta 62, s. $26-39$.

Petrova S. i Solf M., 2009, On the methods of information-structural analysis in historical texts: A case study on Old High German, w: R. Hinterhölzl i S. Petrova (red.), Information Structure and Language Change. New Approaches to Word Order Variation in Germanic, Berllin-New York: Mouton de Gruyter, s. 121-160.

Pinkster H., 1990, Latin syntax and semantics, London-New York: Routledge.

Revuelta Puigdollers A., 2009, The Particles $\alpha \tilde{u}$ and $\alpha \tilde{\tau} \tau \varepsilon$ in Ancient Greek as Topicalizing Devices, w: S. J. Bakker i G. Wakker (red.), Discourse Cohesion in Ancient Greek, Leiden: Brill, s. 83-109.

Ruijgh C. J., 1971, Autour de « $\tau \varepsilon$ épique ». Études sur la syntaxe grecque, Amsterdam: Hakkert. 
SGAll P., 1986, Focus and the question test, Folia Linguistica 7(3-4), s. 301-305.

Sicking C. M. J. i van Ophuijsen J. M., 1993, Two studies in Attic particle usage: Lysias and Plato, Leiden: Brill.

Soвотка P., 2011, Historia badań etymologicznych w świetle koncepcji i metod współczesnej lingwistyki. Etymologizowanie Yāski i Platona, Linguistica Copernicana 6(2), s. 247-294.

SoвоткA P., 2013, Próba klasyfikacji i funkcjonalnego opisu partykuł greckich (uwagi wstępne), w: K. Kleszczowa (red.), Wyrażenia funkcyjne w perspektywie diachronicznej, synchronicznej i porównawczej, Katowice: Wydawnictwo Uniwersytetu Śląskiego (w druku).

Spevak O., 2010, Constituent Order in Classical Latin Prose, Amsterdam-Philadelphia: John Benjamins Publishing Company.

Thrall M. E., 1962, Greek Particles in the New Testament. Linguistic and Exegetical Studies, Leiden: Brill.

Touratier C., 1980, L'accusatif proleptique en latin, Lalies: Actes des Sessions de Linguistique et de Littérature Paris 1, s. 53-56.

Vincent D. i Heisler T., 1999, L'anticipation d'objections : prolepse, concession et réfutation dans la langue spontanée, Revue québécoise de linguistique 27(1), s. $15-31$.

WeIL H., 1844, De l'ordre des mots dans les langues anciennes comparèes aux langues modernes, Paris: Joubert.

WestergaArd M., 2009, Word Order in Old and Middle English: The role of information structure and first language acquisition, Diachronica 26(1), s. 65-102.

Wilson J. R. S., 1995, Thrasymachus and the Thumos: A Further Case of Prolepsis in Republic I, The Classical Quarterly 45(1), s. 58-67.

Zaron Z., 2009, Problemy składni funkcjonalnej, Warszawa: Wydział Polonistyki UW, BEL Studio.

ZEwi T., 1996, Subordinate Nominal Sentences Involving Prolepsis in Biblical Hebrew, Journal of Semitic Studies 41(1), s. 1-20.

\section{Functional Interpretation of Ancient Texts. Two Types of Greek Prolepsis in Medea by Euripides (248-249) and in the Gospel of St. John (12, 12-13)}

( s u m m a r y)

The two parts of the article analyse the possibilities of a functional interpretation, in terms of the theme-rheme devision, of ancient texts. The author discusses examples from Classical Greek and Latin as well as New Testament Greek, especially their word order, grammatical and lexical features. On this basis he proposes an an- 
alytical approach to the description of the linguistic values connected on some degree with the communicative structure of these examples. The contextual procedures of indicating markers of thematic or rhematic elements of the sentences in question should be compared with conclusions drawing on the grammatical and semantic observations on the sentence constituents. The determination of theme and rheme exponents must be made - depending on the language - by verifying the means of coding information structure, relevant to the given language, text type, and time of its composition. A complete description of these means should be proceeded by detailed investigation of, for example, in the case of Ancient Greek: standard and contrastive word order, initial positions of utterances (including semantic description of items involved in these positions), functions of the particles, conjunctions, articles, adverbs, personal pronouns, anaphors et al., syntactic and semantic roles of the constituents, etc. The second part of this article considers information status and value of Greek prolepsis. The author distinguishes morphological, syntactic and lexical prolepsis. The last two types are discussed using examples from Medea by Euripides and the Gospel of St. John. The first example represents syntactic prolepsis, the second one - lexical. Neither the pronoun $\eta \mu \tilde{\alpha} \varsigma^{~ ' w e ' ~ f r o m ~ M e d e a, ~ n o r ~ t h e ~ n o u n ~ p o t v i ́ ~} \omega v$ 'palm branches' from St. John's Gospel are thematic as claimed by some researches. Both syntactic and lexical prolepsis are components of a different level of utterances than the material one. The author postulates to consider them as rhematic rather than thematic. Prolepsis functions like quotation which comments on the whole utterance. 
